\title{
TANGGUNG JAWAB DALAM LEVERING PADA PERJANJIAN JUAL BELI SECARA ONLINE
}

\begin{abstract}
Mulyani Zulaeha
Faculty of Law, University of Lambung Mangkurat Jl.Brigjen H. Hassan Basry Banjarmasin 70124 Telp/Fax: +62-4321658Email: mulyani.zulaeha@yahoo.co.id

Submitted : 23/08/2019 Reviewed 05/09/2019 Accepted:29/09/2019

Abstract:The development of buying and selling transactions today using electronic media has changed the identity of the buying and selling relationship. Buying and selling have no longer conducted in the same place by face to face, but it can be done by people from different locations. Nevertheless, the legal provisions regarding buying and selling are still being applied. Differences that occur related to the transfer of goods (levering) that have been purchased cannot be done directly between the seller and the buyer. According to the provisions of Article 1459 of the Civil Code regarding "The ownership of goods which sold transitional from the buyer as long as the surrender has not been made" Levering in online buying and selling is not done at the same time as the agreement and the role of the parties in levering, namely the shipping service, this can cause problems related to responsibility in the process of transferring these rights. The purpose of this study is to analyze the parties responsible for leveraging in the online purchase agreement. Using normative juridical research, it can be questioned that the responsibility for transferring rights to an online purchase agreement is the seller's responsibility unless agreed otherwise.
\end{abstract}

Keywords: Responsibility; Levering; Online Buying and Selling.

Abstrak: Perkembangan transaksi jual beli saat ini dengan menggunakan media elektronik telah mengubah wajah hubungan jual beli. Jual beli tidak lagi harus dilakukan pada satu tempat yang sama secara face to face, namun dapat dilakukan oleh orang yang berbeda lokasi. Meskipun demikian, ketentuan hukum tentang jual beli tetap berlaku. Perbedaan yang terjadi adalah terkait penyerahan barang (levering) yang telah dibeli tidak dapat dilakukan secara langsung antara penjual dengan pembeli. Menurut ketentuan Pasal 1459 KUHPerdata bahwa "Hak milik atas barang yang dijual tidaklah berpindah kepada si pembeli selama penyerahannya belum dilakukan". Levering pada jual beli online tidak dilakukan dalam waktu yang bersamaan dengan terjadinya kesepakatan dan terdapat peran pihak ketiga 
dalam levering, yaitu pihak jasa pengiriman barang, hal ini dapat menimbulkan permasalahan hukum terkait tanggung jawab dalam proses peralihan hak tersebut. Tujuan penelitian ini adalah menganalisis pihak yang bertanggung jawab pada proses levering perjanjian jual beli secara online. Menggunakan penelitian yuridis normatif dapat dijelaskan bahwa tanggung jawab dalam peralihan hak pada perjanjian jual beli secara online adalah tanggung jawab pihak penjual kecuali jika diperjanjikan lain.

Kata Kunci: Tanggung Jawab; Levering; Jual Beli Online

\section{PENDAHULUAN}

Pesatnya perkembangan teknologi informasi telah membawa manusia pada perubahan gaya hidup, mengubah perilaku dalam berinteraksi dengan manusia lainnya. Teknologi informasi digital yang berkembang saat ini telah mengubah pola kehidupan manusia di berbagai bidang, sehingga secara langsung dapat mempengaruhi munculnya perbuatan hukum baru di masyarakat.

Salah satu perubahan yang paling banyak dipengaruhi oleh perkembangan teknologi informasi digital adalah di bidang transaksi perdagangan. Aktifitas perdagangan yang dilakukan masyarakat sekarang ini banyak dilakukan melalui media internet (electronic commerce). Hubungan perdagangan yang demikian, telah mengubah cara-cara bertransaksi bisnis konvensional serta memecahkan tradisi-tradisi dalam perdagangan konvensional. Dimana hubungan perdagangan dilakukan non face (tidak menghadirkan pelaku bisnis secara fisik). Perjanjian jual beli yang dilakukan melalui media elektronik pada dasarnya sama dengan perjanjian jual beli yang dilakukan secara konvensional. Hal yang membedakannya yaitu posisi atau lokasi para pihak yang berlainan serta media yang digunakan yaitu dilibatkannya teknologi komputer dan telekomunikasi sebagai sarana utama.

Perjanjian jual beli yang dilakukan secara online dengan menggunakan internet sebagai medium pada dasarnya memiliki prinsip yang sama dengan perjanjian yang dilakukan secara konvensional. Perbedaannya adalah dilibatkannya teknologi komputer dan telekomunikasi secara intensif sebagai sarana untuk melakukan transaksi. Dengan menggunakan internet sebagai media maka para pihak dalam perjanjian yang dilakukan secara elektronik dilakukan tanpa kehadiran fisik pihakpihak yang melakukan transaksi dan dengan semua atau sebagian proses dilakukan dengan menggunakan media internet sehingga hampir semua tahapan perjanjian dalam jual beli secara elektronik dilakukan secara online.

Menurut Pasal 1458 KUH Perdata "Jual beli dianggap telah terjadi antara kedua belah pihak seketika setelah orang-orang mencapai sepakat tentang kebendaan tersebut dan harganya, meskipun kebendaan itu belum diserahkan, maupun harganya belum dibayar". Dengan demikian dalam jual beli yang dilakukan secara elektronik ketika pembeli menyetujui penawaran barang atau produk yang ditawarkan dalam online shopping melalui pernyataan dengan cara mengklik "ok" atau "setuju" atas barang tersebut maka perjanjian jual beli yang berlaku di situs tersebut dapat dikatakan sah dan mengikat para pihak yang karenanya menimbulkan hak dan kewajiban. Namun walaupun sudah mengikat perjanjiannya bagi para pihak, menurut Pasal 1459 KUHPerdata 
"Hak milik atas barang yang dijual tidaklah berpindah kepada si pembeli selama penyerahannya belum dilakukan". Mengingat jual beli secara elektronik posisi penjual dan pembeli yang berjauhan, maka permasalahan yang dapat terjadi adalah berkaitan tanggung jawab dalam pemenuhan salah satu unsur pokok dari perjanjian yaitu unsur perbuatan, berupa penyerahan barang (levering) sebagai wujud terjadinya peralihan hak atas barang yang menjadi objek dalam jual beli secara online.

\section{METODE}

Penelitian ini menggunakan jenis penelitian yuridis normatif, yaitu penelitian hukum yang dilakukan untuk menjawab isu hukum dengan mengkaji dan menganalisis ketentuan perundang-undangan sebagai bahan hukum primer dan bahan hukum lainnya yaitu bahan bahan hukum sekunder dan bahan hukum tersier.

Penelitian ini menggunakan pendekatan perundang-undangan (statute approach), dan pendekatan konsep (conseptual approach). Pendekatan undang-undang dilakukan dengan menelaah semua undang-undang dan regulasi yang bersangkut paut dengan isu hukum yang diangkat, pendekatan konsep dilakukan dengan cara melakukan penelusuran terhadap pandangan-pandangan dan doktrin-doktrin yang berkembang dalam ilmu hukum yang bersumber dari pendapat para ahli maupun teori.

Semua bahan hukum primer dan bahan hukum sekunder yang telah dikumpulkan, diklasifikasi, dan di kategorisasikan sesuai dengan isu hukum. Dalam penelitian ini analisis terhadap bahan hukum dilakukan secara preskriptif analitis, yaitu bertujuan untuk menghasilkan preskripsi mengenai apa yang seharusnya sebagai esensi dalam penelitian hukum yang berpegang pada karakter ilmu hukum sebagai ilmu terapan.

\section{ANALISIS DAN PEMBAHASAN Analisis Karakteristik Levering Dalam Jual Beli Online}

Konsep peraturan hukum tidak selalu tetap penyusunannya di setiap waktu. Dengan kata lain, konsep-konsep atau elemen-elemen penting di dalam peraturan hukum tidak dapat disusun sekali saja untuk selama-lamanya. Sulit untuk menerapkan konsep secara utuh, konsisten dan teratur sepanjang waktu. ${ }^{1}$ Sehingga suatu konsep yang terdapat dalam peraturan hukum dapat saja dilakukan perubahan manakala sudah tidak sesuai lagi. Perkembangan jual beli saat ini dari konvensional menjadi jual beli secara online, melahirkan suatu hal baru terutama tentang konsep penyerahan (levering). Konsep menurut Satjipto Rahardjo yaitu sama dengan pengertian-pengertian yang merupakan abstraksi dari barang-barang yang pada dasarnya bersifat konkret, individual. ${ }^{2}$ Bruggink menyebutkan, pengertian adalah isi pikiran yang dimunculkan oleh sebuah perkataan tertentu kepada sebuah objek atau seseorang. ${ }^{3}$ Menurut perspektif hukum, pengertian sangat penting karena sebuah peraturan perundang-undangan yang ditujukan pada masyarakat harus dibuat dengan jelas pada masyarakat itu, perilaku apa yang diharapkan dari peraturan perundang-undangan itu, oleh karenanya banyak peraturan perundang-undangan sebelum pengaturan yang sesungguhnya (pasal-pasal) dalam isinya

1 Tom Bingham. 2000. The Rule of Law. London: Penguins Book,hlm 14.

2 Satjipto Rahardjo.2006. Hukum Dalam Jagat Ketertiban. Jakarta: Nuansa Cipta Warna, hlm 20.

3 Bruggink dalam Arief B. Sidharta. 1999. Refleksi Tentang Hukum. Bandung: Citra Aditya Bhakti, hlm 46. 
memberikan batasan pengertian terlebih dahulu tentang pengertian-pengertian yang akan digunakan dalam ketentuan umum peraturan perundang-undangan tersebut.

Menurut John Chipman Gray, ${ }^{4}$ problem dalam menentukan sebuah konsep baru tentang hukum antara lain baik hukum negara ataupun hukum yang ada pada setiap badan yang terorganisasi apapun juga, merupakan aturan-aturan yang kelak menjadi dasar bagi pengadilan dalam menetapkan apa yang menjadi hak dan kewajiban hukum. Konsep atau pengertian hukum yang dibuat dipengaruhi pula oleh waktu dan tempat. Menurut Achmad Ali, ${ }^{5}$ kendala mendefinisikan hukum meliputi dua hal yaitu secara internal dan secara eksternal. Secara internal, pertama karena sifat hukum yang abstrak meskipun manifestasinya dalam dalam wujud penegak hukumnya dan dan perundang-undangan dalam berwujud konkret. Kedua, objek yang diatur oleh hukum sangat luas. Secara eksternal adalah kesulitan dari segi kata-kata.

Untuk itu, diperlukannya prinsip hukum karena, pertama, prinsip hukum menurut Bryan A. Garner adalah a basic rule, law, or doctrine. ${ }^{6}$ Selanjutnya Paul Scholten mengemukakan bahwa prinsip hukum adalah pikiran-pikiran dasar yang terdapat di dalam dan di belakang sistem hukum, masing-masing dirumuskan dalam aturan-aturan perundangundangan dan putusan-putusan hakim yang berkenaan dengannya ketentuan-ketentuan dan keputusan-keputusan individual dapat di-

4 John Chipman Gray dalam Achmad Ali. 2009. Menguak Teori Hukum (Legal Theory) Dan Teori Peradilan (Judicial Prudence) Termasuk Interpretasi Undang-Undang (Legisprudence). Jakarta : Prenada Media Group,hlm 399.

$5 \quad$ Ibid. hlm 406-407.

6 Bryan A. Garner. 2004. Black Law's Dictionary. $8^{\text {th }}$ edition. USA: Thompson West Group, hlm 1231. pandang sebagai penjabarannya. ${ }^{7}$

Kedua, menurut Bellefroid, asas atau prinsip hukum adalah norma dasar yang dijabarkan dari hukum positif dan yang oleh ilmu hukum tidak dianggap berasal dari aturan-aturan yang lebih umum, jadi prinsip hukum merupakan kristalisasi hukum positif dalam masyarakat. ${ }^{8}$ Namun Van Eikema Homes memberikan batasan bahwa prinsip bukan norma hukum yang konkret, tetapi sebagai dasar-dasar umum atau petunjuk-petunjuk bagi hukum yang berlaku. Jadi merupakan dasar atau petunjuk arah dalam pembentukan hukum positif, sehingga dalam pembentukan hukum praktis harus berorientasi pada asasasas hukum. ${ }^{9}$

Ketiga, Satjipto Rahardjo menjelaskan bahwa prinsip hukum dapat diartikan sebagai suatu hal yang dianggap oleh masyarakat hukum yang bersangkutan sebagai basic truth atau kebenaran asasi, sebab melalui asas-asas hukum itulah pertimbangan etis dan sosial masyarakat masuk ke dalam hukum. Dengan demikian asas hukum menjadi semacam sumber untuk menghidupi tata hukumnya dengan nilai-nilai etis, moral dan sosial masyarakatnya. ${ }^{10}$

Keempat, G.W. Paton menganggap prinsip hukum merupakan jantung atau hatinya norma hukum. Hal ini berdasarkan pemikiran bahwa prinsip hukum merupakan landasan yang paling luas bagi lahirnya suatu norma hukum. Dengan demikian setiap norma

7 Paul Scholten dalam Johanes Ibrahim.2004. Cross Default and Cross Collateral. Bandung: Refika Aditama, hlm 11.

8 Sudikno Mertokusumo. 2003. Mengenal Hukum (Suatu Pengantar). Yogyakarta: Liberty, hlm 34.

9 Agus Yudha Hernoko. 2008. Hukum Perjanjian: Asas Proporsionalitas Dalam Kontrak Komersial. Yogyakarta: LBM, hlm 19.

10 Ibid, hlm 12. 
hukum itu dapat dikembalikan kepada prinsipnya. Prinsip hukum tersebut merupakan ratio logis dari norma hukum. Prinsip hukum tidak akan pernah habis kekuatannya dengan melahirkan norma hukum, melainkan tetap ada dan akan terus melahirkan norma-norma hukum baru. ${ }^{11}$ Jantungnya peraturan yang mencerminkan tujuan hukum terdapat dalam asas hukum. asas hukum merupakan jantungnya hukum dan ia merupakan landasan yang paling luas bagi lahirnya suatu peraturan hukum. Bruggink menyatakan bahwa asas/prinsip hukum adalah nilai-nilai yang mendasari norma hukum. ${ }^{12}$ Asas hukum membuat hukum itu hidup, tumbuh dan berkembang dan ia juga menunjukkan bahwa hukum itu bukan sekedar kumpulan peraturan-peraturan belaka, karena asas mengandung nilai-nilai dan tuntunan-tuntunan etis.

Meskipun prinsip hukum bukan merupakan suatu norma hukum, namun tidak ada suatu norma hukum yang dapat dipahami tanpa mengetahui prinsip-prinsip hukum yang terdapat di dalamnya. ${ }^{13}$ Menurut Ronald Dworkin prinsip hukum memiliki bobot yang merefleksikan dimensi atau kualitas, sehingga prinsip hukum berguna sebagai penyeimbang khususnya terhadap peraturan hukum. Prinsip hukum bukan saja sekadar rambu-rambu tetapi hakikatnya melahirkan kekuatan mengikat hukum. ${ }^{14}$

Transaksi elektronik adalah jual beli yang terjadi di dunia maya atau jual beli secara online. Sehingga ketentuan tentang jual beli

$11 \quad$ Ibid,hlm 20.

12 Bruggink dalam Arief B. Sidharta, Op.Cit. hlm25.

13 Satjipto Rahadjo. Op.Cit, hlm 47.

14 Ronald Dworkin.2002. Conception of Law and Morality. dalam Wayne Morrison. Jurisprudence From the Greeks to Post Modernity. UK: Cavendish Publishing. Terjemahan Zhang Wan Hong, hlm 144-148. sebagaimana dalam jual beli konvensional pada dasarnya juga berlaku pada transaksi elektronik. Yang berbeda adalah jika dalam jual beli konvensional para pihak berhadapan langsung dan objek perjanjian dapat dilihat, diraba secara fisik maka dalam transaksi elektronik perjanjian jual beli dilakukan secara virtual dan objek jual beli tidak dapat dilihat dan diraba secara fisik karena ia hanya berupa visualisasi gambar dan deskripsi produk.

Jual beli secara umum terdapat dalam Pasal 1457 KUH Perdata yaitu perjanjian dengan mana pihak penjual mengikatkan diri untuk menyerahkan benda dan pihak pembeli untuk membayar harga yang telah disetujui. Rumusan ini mengandung empat unsur pokok, yaitu unsur subyek, obyek, perbuatan, dan tujuan. Unsur subyek terdiri dari penjual dan pembeli. Unsur obyek terdiri dari benda dan harga. Benda dapat berupa barang konsumsi untuk dipakai sendiri dan barang dagangan untuk diperjualbelikan. Harga dapat dibayar tunai dan dapat pula secara kredit. Unsur perbuatan terdiri dari menjual dengan penyerahan barang dan membeli dengan pembayaran harga. Penyerahan barang dapat secara langsung maupun menggunakan alat angkut khusus. Unsur tujuan terdiri dari peralihan hak, memperoleh kenikmatan, memperoleh keuntungan atau laba yang diperhitungkan.

Objek dari jual beli adalah barang/benda, baik benda bergerak maupun tidak bergerak, berwujud maupun tidak berwujud. ${ }^{15}$ Pengertian benda secara yuridis menurut Pasal 499 KUHPerdata adalah "segala sesuatu yang dapat dihaki atau yang dapat menjadi objek hak milik". Benda tidak bergerak diatur dalam Pasal 506, 507 dan 508 KUH Perdata yang

15 Sebagian besar pasal-pasal dalam Buku II KUHPerdata adalah mengatur mengenai benda dalam arti benda yang berwujud 
digolongkan menjadi 3 golongan yaitu:

1. Benda yang menurut sifatnya tidak bergerak, seperti tanah, segala sesuatu yang bersatu dengan tanah karena tumbuh dan berakar serta bercabang seperti tumbuh-tumbuhan, buah-buahan yang masih belum dipetik, segala sesuatu yang bersatu dengan tanah karena didirikan diatas tanah itu yaitu karena tertanam dan terpaku.

2. Benda yang menurut tujuannya/tujuan pemakaiannya supaya bersatu dengan benda tidak bergerak seperti pabrik : segala mesin-mesin, dan alat-alat lain yang dimaksudkan supaya terus menerus berada disitu untuk dipergunakan dalam menjalankan pabrik, pada suatu perkebunan : segala sesuatu yang dipergunakan sebagai rabuk bagi tanah atau ikan dalam kolam, pada rumah kediaman : segala kaca, tulisan-tulisan dan alat-alat untuk menggantungkan barang-barang sebagai bagian dari dinding, barang-barang reruntuhan dari suatu bangunan apabila dimaksudkan untuk dipakai guna mendirikan lagi bangunan itu.

3. Benda yang menurut penetapan undangundang sebagai benda tidak bergerak seperti hak-hak atau penagihan suatu benda yang tidak bergerak, kapal-kapal yang berukuran 20 meter kubik keatas.

Benda bergerak diatur dalam Pasal 509, 510 dan 511 KUHPerdata yang digolongkan menjadi dua yaitu benda yang menurut sifatnya bergerak dalam arti benda itu dapat berpindah atau dipindahkan dari suatu tempat ketempat yang lain. Misalnya sepeda, kursi, dan sebagainya. Benda yang menurut penetapan undang-undang sebagai benda bergerak ialah segala hak atas benda-benda bergerak. Misalnya hak memetik hasil dan hak memakai, hak atas bunga, dan lain-lain. Perbedaan antara benda tidak bergerak dengan benda bergerak adalah penting artinya karena adanya ketentuan-ketentuan khusus yang berlaku bagi masing-masing golongan benda tersebut seperti hak bezit, mengenai pembebanan (bezwaring), mengenai penyerahan (levering), mengenai daluarsa (verjaring) dan mengenai penyitaan (beslag).

Hak kebendaan adalah hak yang paling sempurna. Orang yang mempunyai hak milik atas sesuatu benda dapat menikmati kegunaannya dengan sepenuhnya dan dapat berbuat sebebas-bebasnya atas benda tersebut. Artinya pemilik benda itu dapat menjual, menyewakan, menggadaikan, menukarkan, memberikan bahkan menghancurkan benda yang dimilikinya asalkan tidak melanggar undang-undang dan tidak menimbulkan gangguan terhadap hak-hak orang lain. Sebagai hak kebendaan yang paling sempurna hak milik mempunyai ciri-ciri sebagai berikut, hak milik merupakan hak induk terhadap hak-hak kebendaan yang lain sedangkan hak-hak kebendaan lain adalah hak anak terhadap hak milik, hak milik ditinjau dari kualitasnya merupakan hak yang selengkap-lengkapnya, hak milik bersifat tetap artinya tidak akan lenyap terhadap hak kebendaan orang lain sedangkan hak kebendaan yang lain dapat lenyap jika menghadapi hak milik, hak milik mengandung inti dari hak kebendaan yang lain sedangkan hak kebendaan yang lain hanya merupakan bagian saja hak milik.

Cara memperoleh hak milik diatur dalam Pasal 584 KUH Perdata yang menyebutkan secara limitatif bagaimana cara-cara memperoleh hak milik tersebut, yaitu: ${ }^{16}$

\section{Pengambilan (toegening /occupation),}

16 Cara memperoleh hak milik dengan penyerahan (levering) berupa jual beli adalah cara memperoleh 
yaitu cara memperoleh hak milik dengan mengambil benda-benda bergerak yang sebelumnya tidak ada pemiliknya (res nullius) seperti binatang-binatang buruan di hutan;

2. Penarikan oleh benda lain (natrekking/ accession), yaitu cara memperoleh hak milik dimana benda yang dimiliki sebelumnya bertambah besar atau banyak misalnya pohon yang berbuah;

3. Lewat waktu/daluarsa (verjaring), yaitu cara memperoleh hak milik karena lampaunya waktu;

4. Pewarisan (erfopvolging), yaitu cara memperoleh hak milik bagi para ahli waris atas boedel warisan yang ditinggalkan pewaris;

5. Penyerahan (levering), yaitu cara pemindahan hak milik dari seseorang yang berhak memindahkannya kepada orang lain yang memperoleh hak milik misalnya dengan jual beli.

Berdasarkan Pasal 584 KUH Perdata tersebut, maka dalam jual beli cara memperoleh hak milik dilakukan melalui penyerahan (levering). Konsep levering pada perjanjian jual beli yang dilakukan secara online memiliki karakteristik yang berbeda dengan levering dalam jual beli secara konvensional. Menggunakan analisis berdasarkan pendapat G.W. Paton bahwa untuk melakukan pendefinisian karakteristik hukum maka secara logis terlebih dahulu harus dicari genus dari persoalan yang ingin didefinisikan, setelah itu dicari sifat-sifat khas yang membedakannya dengan yang lain. ${ }^{17}$ Berdasarkan pendapat G.W Paton ini, maka secara umum lever-

hak milik yang paling banyak dilakukan dalam kehidupan masyarakat sekarang.

17 GW. Paton dalam Achmad Ali. 2009. Op.Cit. hlm 407. ing perjanjian jual beli secara konvensional merupakan genus dari persoalan yang akan didefinisikan, sifat-sifat khusus atau karakter khas yang akan didefinisikan dalam levering (genus) yaitu levering pada perjanjian jual beli secara online. Dengan demikian dapat ditarik suatu karakteristik levering pada perjanjian jual beli secara online adalah antara penjual dan pembeli tidak berada dalam satu tempat yang sama pada waktu terjadinya jual beli. Jarak antara penjual dan pembeli bisa saja terjadi dalam satu kota yang sama, bahkan terpaut puluhan kilometer jaraknya, sehingga penyerahan tidak dapat dilakukan secara langsung.

Berdasarkan analisis maka karakteristik levering dalam jual beli online secara genus mempunyai definisi yang sama dengan konsep levering pada jual beli secara konvensional, namun levering dalam jual beli melalui transaksi elektronik memiliki sifat-sifat khas yang membedakan yaitu levering tidak dilakukan dalam waktu yang bersamaan dengan terjadinya kesepakatan dan terdapat peran pihak ketiga dalam levering, yaitu pihak jasa pengiriman barang.

\section{Analisis Tanggung Jawab dalam Levering Jual Beli Online}

Menurut sistem hukum perdata ciri khas dari perjanjian jual beli yaitu hanya melahirkan kewajiban saja yaitu kewajiban untuk menyerahkan barangnya bagi si penjual dan kewajiban untuk membayar harganya bagi pembeli, tetapi tidak berakibat berpindahnya hak milik atas barang. Hak milik atas barang baru berpindah kepada si pembeli setelah adanya levering. ${ }^{18}$

18 Konsep tentang perpindahan hak milik dalam jual beli terjadi setelah adanya penyerahan yang dianut oleh KUHPerdata adalah senada dengan konsep 
Levering menurut hukum perdata adalah penyerahan suatu benda oleh oleh eigenaar atau atas namanya kepada orang lain sehingga orang lain ini memperoleh hak milik atas benda itu. Pasal 1475 KUH Perdata menyatakan "penyerahan adalah suatu pemindahan barang yang telah dijual kedalam kekuasaan dan kepunyaan pembeli”. Perkataan levering mempunyai dua arti. Pertama, berarti perbuatan berupa penyerahan kekuasaan belaka (feitelijke levering) atas suatu benda. Kedua, berarti perbuatan hukum yang bertujuan memindahkan hak milik kepada orang lain (jurisdishe leveing). Levering sebagai perbuatan yuridis (jurisdishe leveing) dalam arti transfering of ornership merupakan lembaga hukum yang hanya dikenal khusus dalam sistem hukum perdata Indonesia. ${ }^{19}$

Macam-macam cara levering dibedakan berdasarkan sifat dari benda, yaitu benda bergerak atau benda tidak bergerak. Benda bergerak dibedakan lagi atas benda berwujud dengan benda yang tidak berwujud. Levering

jual beli berdasarkan hukum adat yaitu dalam hukum adat jual beli diartikan sebagai penyerahan barang untuk selama-lamanya dengan menerima harga-uang. Semua perjanjian menurut hukum adat merupakan reele overeekomst artinya perjanjian itu membutuhkan disamping persetujuan (perizinan) kedua belah pihak, juga tindakan nyata yang dapat dilihat (kontante handeling).

19 Dalam sistem hukum perdata yang menganut Code Civil misalnya di Perancis tidak mengenal lembaga levering. Dalam Code Civil Perancis jual beli tidak bersifat obligatoir melainkan bersifat konsensual dimana jual beli sudah memindahkan hak milik atas barang yang diperjualbelikan (deliverance) ketika tercapainya kata sepakat, sehingga penyerahan dalam hal ini hanyalah merupakan kekuasaan belaka (feitelijke daad) atas barang yang sebenarnya hak miliknya sudah berpindah sewaktu perjanjian jual beli ditutup. Prinsip konsensual dalam jual beli juga dianut oleh prinsip-prinsip dasar kontrak internasional yang termuat dalam UNIDROIT dan CISG. benda bergerak yang berwujud menurut Pasal 612 ayat (1) KUH Perdata dilakukan dengan penyerahan nyata (feitelijke levering) atau dari tangan ke tangan akan kebendaan itu oleh atau atas nama pemilik, atau dengan penyerahan kunci-kunci dari bangunan dalam mana benda itu berada. Akan tetapi menurut Pasal 612 ayat (2) KUH Perdata adakalanya penyerahan terhadap benda-benda bergerak yang berwujud itu pada peralihan hak tidak perlu dilakukan yaitu dalam hal benda yang akan diserahkan itu telah berada dalam tangan orang yang hendak menerimanya berdasarkan alas hak yang lain.

Mengenai penyerahan yang dimaksud dalam Pasal 612 ayat (2), dalam hukum perdata mengenal 2 (dua) macam figur penyerahan, yaitu:

1. Traditio brevi menu (penyerahan dengan tangan pendek) Misalnya A meminjam buku B. B eigenaar buku itu, kemudiaan karena B memerlukan uang ia lalu menjual buku itu kepada A. Dalam hal demikian itu levering tidak diperlukan sebab buku itu sudah ada pada A berdasarkan hubungan hukum pinjam meminjam. A tadinya sebagai peminjam berubah menjadi eigenaar.

2. Constitutum pessessorium (penyerahan dengan melanjutkan penguasaan atas bendanya) Misalnya A eigenaar dari sebuah buku karena membutuhkan uang ia menjual buku tersebut kepada B. Akan tetapi A masih membutuhkan buku itu untuk mempelajarinya, maka A kemudian meminjam buku itu dari B (eigenaar buku ) Dalam hal ini A tadinya sebagai eigenaar berubah menjadi peminjam.

Levering dari benda bergerak yang tidak berwujud dapat dibedakan yaitu piutang oop naam (atas nama) menurut Pasal 613 ayat (1) 
KUH Perdata dilakukan dengan membuat akta otentik atau akta dibawah tangan. Levering atas surat piutang aan tonder (atas tunjuk atau atas bawa) menurut Pasal 613 ayat (3) KUH Perdata dilakukan dengan penyerahan surat itu. Sedangkan levering piutang aan order (atas perintah) menurut Pasal 613 ayat (3) KUH Perdata dilakukan dengan penyerahan surat itu disertai dengan endossemen.

Syarat-syarat yang harus dipenuhi untuk sahnya levering adalah: ${ }^{20}$

1. Harus ada perjanjian yang zakelijk;

2. Harus ada titel (alas hak);

3. Harus dilakukan oleh orang yang wenang menguasai benda-benda (orang yang besckikkingsbevoed);

4. Harus ada penyerahan nyata.

Perjanjian yang zakelijk, merupakan perjanjian yang menimbulkan atau menyebabkan pindahnya hak-hak kebendaan (zakelijke rechten) misalnya eigendom. Dalam perjanjian jual beli tidak dapat menyebabkan beralihnya eigendom hanya menyebabkan verbintennis yaitu yang satu harus memberikan prestasi (yaitu menyerahkan benda) dan yang lain berhak atas prestasi itu. Tapi perjanjian belum mengakibatkan eigendom atas benda baru setelah levering maka eigendom itu beralih. Jadi perjanjian obligatoir tidak menimbulkan atau menyebabkan pindahnya hak zakelijk melainkan hanya menimbulkan hak-hak persoonlijk.

Harus ada titel (alas hak) adalah hubungan yang mengakibatkan levering. Hubungan hukum yang paling sering/biasanya mengakibatkan levering ialah perjanjian jual beli, tukar menukar dan perjanjian pemberian hadiah. Syarat harus adanya titel ini diatur dalam

20 Sri Soedewi Mascjhun Sofwan.1976. Hukum Perdata : Hukum Benda. Yogyakarta : Seksi Hukum Perdata Fakultas Hukum UGM, hlm 64.
Pasal 584 KUHPerdata yaitu "Hak milik atas sesuatu kebendaan tak dapat diperoleh dengan cara lain melainkan dengan pemilikan karena perlekatan, karena daluarsa, karena pewarisan baik menurut undang-undang maupun menurut surat wasiat dan karena penunjukan atau penyerahan berdasar atas suatu peristiwa perdata untuk memindahkan hak milik, dilakukan oleh seorang yang berhak berbuat bebas terhadap kebendaan itu".

Berkaitan dengan alas hak ini sebagai dasar terjadinya levering terdapat beberapa pendapat yang pokoknya ada dua macam, yaitu Ajaran Causaal dan Ajaran Abstract. Menurut Ajaran Causaal, untuk sahnya levering itu tergantung pada alas haknya. Jika alas haknya tidak sah juga leveringnya tidak sah. Untuk sahnya levering diperlukan titel yang nyata atau titel yang riil. Jadi antara alas dan haknya levering itu ada hubungan causaal. Ajaran Causaal dikemukakan oleh Diephuis dan Scholten. Sedangkan menurut Ajaran Abstract, penyerahan dan alas hak itu merupakan hal-hal yang terpisah satu sama lain. Untuk sahnya levering tidak tergantung pada alas hak yang nyata. Sehingga menurut Ajaran Abstract yang murni, konsekuensinya bisa terjadi bahwa levering itu akan sah juga sekalipun titelnya tidak sah bahkan sekalipun tanpa titel. Tokoh dari Ajaran Abstract adalah Opzoomer dan Meijers. ${ }^{21}$

Pasal 584 KUH Perdata mengikuti Ajaran Causaal, karena menurut pasal ini untuk sahnya levering itu mengharuskan adanya titel. Ajaran Abstract beranggapan ketentuan yang menyatakan levering yang berdasarkan titel harus ditafsirkan bahwa sahnya levering tidak perlu adanya titel yang nyata cukup asal ada titel anggapan saja atau cukup adanya putatieve titlel. Pada dasarnya kedua ajaran

21 Ibid. hlm 66 
menyatakan bahwa untuk sahnya levering mengharuskan adanya titel, hanya bedanya Ajaran Causaal mengharuskan adanya titel yang nyata/riil sedangkan Ajaran Abstract cukup adanya titel anggapan. Syarat ketiga sahnya levering adalah harus dilakukan oleh orang yang wenang menguasai benda-benda (besckikkingsbevoed), syarat ini adalah pelaksaaan dari suatu azas hukum yaitu Azas $\mathrm{Ne}$ moplus, yaitu bahwa seseorang itu tidak dapat memperalihkan hak melebihi apa yang menjadi haknya. Dan lazimnya yang wenang untuk menguasai benda itu ialah eigenaar.

Syarat keempat sahnya levering adalah penyerahan yang nyata. Penyerahan nyata (feitelijke levering) yaitu penyerahan dari tangan ke tangan. Feitelijke levering harus dibedakan dengan jurisdische levering. Dari perjanjian-perjanjian yang obligatoir itu timbul dua macam kewajiban penyerahan yaitu harus ada penyerahan nyata dan harus ada penyerahan yuridis, yang biasanya dicakup dalam satu kata saja yaitu levering. Pada benda bergerak penyerahan nyata dan penyerahan yuridis jatuh bersamaan sebagaimana dalam Pasal 612 ayat (1) penyerahan itu terjadi dengan overgave menyerahkan benda itu. Pada benda tidak bergerak kedua macam levering itu berpisah, feitelijke levering terjadi dengan penyerahan kunci dari suatu rumah atau pembukaan dari pagarnya dan lain-lain sedangkan jurisdische levering terjadi pada saat dibuatnya akte perpindahan hak dihadapan Pejabat Pembuat Akta Tanah (PPAT).

Dalam transaksi jual beli secara elektronik yang objek perjanjiannya pada umumnya adalah benda bergerak yang berwujud dan menurut sifatnya bergerak dalam arti benda itu dapat berpindah atau dipindahkan dari suatu tempat ketempat yang lain kecuali he- wan $^{22}$. sehingga dalam hal jual beli pada jual beli secara elektronik penyerahannya dilakukan dengan menggunakan penyerahan nyata (feitelijke levering). Namun karena sifat jual beli secara online yang tidak face to face pada satu tempat, maka penyerahan dilakukan dengan melibatkan pihak ketiga yaitu jasa pengiriman. Keterlibatan jasa pengiriman pada proses penyerahan adalah berdasarkan hubungan hukum antara pihak penjual dengan jasa pengiriman yaitu perjanjian pengiriman barang. Dalam perjanjian itu pihak penjual berkewajiban membayar jasa pengiriman barang pesanan konsumen ke alamat yang sudah diberikan konsumen, sedangkan jasa pengiriman berkewajiban dan menjamin barang yang telah diserahkan pihak penjual untuk dikirim ke alamat konsumen. Macam-macam bentuk penyerahan sesuai dengan kesepakatan para pihak adalah:

1. Loco artinya gudang penjual, ini berarti bahwa pembeli menerima penyerahan barang di gudang penjual, sehingga resiko dan hak milik atas barang beralih kepada pembeli mulai saat barang diangkut ke luar gudang penjual. Semua biaya pengangkutan dan kerusakan barang mulai dari gudang penjual sampai di gudang atau tempat pembeli menjadi tanggung jawab pembeli;

2. F.A.S. (Free Alongside Ship), berarti bebas disamping kapal. Bentuk ini adalah penyerahan barang dilakukan di dermaga di samping kapal yang disediakan oleh pembeli di pelabuhan embarkasi. Hak milik atas barang beralih kepada pembeli sejak saat barang ditempatkan di dermaga disamping kapal. Semua biaya muat, bi-

22 Edmon Makarim. 2005. Pengantar Hukum Telematika: Suatu Kompilasi Kajian. Jakarta: Rajagrafindo Persada, hlm. 268. 
aya angkutan, biaya pembongkaran dan kerugian sampai digudang pembeli menjadi tanggung jawab pembeli;

3. F.O.B. (Free on Board), artinya bebas diatas kapal. Bentuk ini mengandung arti bahwa penyerahan barang dilakukan diatas kapal yang disediakan oleh pembeli di pelabuhan embarkasi. Hak milik dan resiko atas barang beralih kepada pembeli sejak saat barang berada diatas kapal. Semua biaya angkutan dan kerugian sampai diatas kapal menjadi tanggung jawab penjual sedangkan semua biaya dan kerugian dari atas kapal sampai di gudang pembeli menjadi tanggung jawab pembeli;

4. C.I.F (Cost, Insurance, and Freight), artinya adalah ongkos, premi asuransi, dan biaya angkutan. Bentuk ini mengandung arti bahwa semua ongkos, biaya angkutan dan premi asuransi barang sampai dipelabuhan pembongkaran menjadi tanggung jawab penjual. Penjual harus mengantarkan barang sampai dipelabuhan pembeli. Tetapi peralihan resiko dari penjual kepada pembeli sejak barang berada diatas kapal di pelabuhan embarkasi (pemuatan). Dalam bentuk ini beralihnya hak milik ada dua kemungkinan, yaitu pertama, jika tidak terjadi penjualan barang sesudah pemuatan, maka hak milik berpindah pada saat pemuatan diatas kapal. Kedua, jika terjadi penjualan barang sesudah pemuatan, maka hak milik berpindah pada saat penyerahan konosemen $^{23}$ kepada pembeli;

5. C.F. (Cost and Freight), artinya ongkos dan biaya angkutan. Bentuk ini sama dengan C.I.F. Bedanya terletak pada premi

23 Konosemen adalah surat bukti pengangkutan barang yang berisi daftar barang yang dikirimkan oleh penjual kepada pembeli. asuransi . Pada C.F premi asuransi menjadi tanggung jawab pembeli, sedangkan dalam C.I.F menjadi tanggung jawab penjual. Franco artinya bebas. Ini berarti bahwa penjual harus menyerahkan barang di gudang pembeli. Hak milik dan resiko beralih kepada pembeli pada saat barang berada di gudang pembeli. Pembeli bebas dari segala biaya dan resiko sebelum barang sampai digudangnya, sebab itu adalah tanggung jawab penjual. Sering juga dalam praktek dibelakang kata franco ditambah dengan nama tempat, mialnya franco Jakarta, ini berarti bahwa semua biaya pengangkutan dan resiko atas barang sampai di Jakarta menjadi beban penjual, karena penyerahan barang terjadi di Jakarta maka peralihan resiko kepada pembeli juga di Jakarta. ${ }^{24}$

Dalam hal saat penyerahan terjadi suatu keadaan yang diluar kehendak atau suatu keadaan memaksa maka keadaan yang demikian dapat membebaskan seseorang dari kewajiban membayar ganti rugi. Suatu keadaan diluar kehendak atau tidak terduga ini diatur dalam Pasal 1244 KUHPerdata yaitu: "Jika ada alasan untuk itu siberutang harus dihukum mengganti biaya rugi dan bunga apabila ia tidak dapat membuktikan bahwa hal tidak atau tidak pada waktu yang tepat dilaksanakannya perikatan itu disebabkan karena suatu hal yang tidak terduga pun tidak dapat dipertanggungjawabkan padanya, kesemuanya itupun jika itikad buruk tidaklah ada pada pihaknya."

Menurut pasal tersebut ada 3 (tiga) unsur yang harus dipenuhi untuk keadaan memak-

24 Abdul Kadir Muhammad. 1991. Pengantar Hukum Perusahaan Indonesia. Bandung: Citra Aditya Bakti, hlm 173. 
sa, yaitu, tidak memenuhi prestasi, ada sebab yang terletak diluar kesalahan debitur dan faktor penyebab itu tidak diduga sebelumnya dan tidak dapat dipertanggungjawabkan kepada debitur.

Keadaan memaksa mengakibatkan perjanjian tersebut tidak lagi bekerja, walaupun perjanjiannya sendiri tetap ada. Atau dengan kata lain dengan adanya keadaan yang memaksa maka pada asasnya perjanjian itu tetap ada dan yang lenyap hanyalah daya kerjanya. Dalam hal ini maka:

1. Kreditur tidak dapat menuntut agar perjanjian itu dipenuhi;

2. Tidak dapat mengatakan debitur berada dalam keadan lalai dan karena itu tidak dapat dapat menuntut;

3. Kreditur tidak dapat meminta pemutusan perjanjian;

4. Pada perjanjian timbal balik maka gugur kewajiban untuk melakukan kontra prestasi;

Dalam sejarah pemikiran tentang keadaan memaksa terdapat 2 (dua) aliran atau ajaran yaitu: $:^{25}$

1. Ajaran yang objektif (de objective overmachtsleer)

Menurut ajaran keadaan memaksa objektif, debitur berada dalam kedaan memaksa apabila pemenuhan prestasi itu tidak mungkin dilaksanakan oleh siapapun juga atau oleh setiap orang. Misalnya A harus menyerahkan kuda kepada B, kuda ditengah jalan disambar petir, hingga oleh siapapun juga penyerahan kuda itu tidak mungkin dilaksanakan. Dalam ajaran ini para sarjana tertuju pada bencana alam atau kecelakaan yang hebat, sehingga

25 Mariam Darus Badrulzaman. 2001. Kompilasi Hukum Perikatan. Bandung : Citra Aditya Bakti, hlm. 26-27. dalam keadaan demikian siapapun tidak dapat memenuhi prestasi. Juga jika barang musnah atau hilang diluar perdagangan dianggap sebagai keadaan memaksa.

Berkaitan dengan ini terdapat dalam Pasal 1444 KUH Perdata, dimana disebutkan "Jika barang tertentu yang menjadi bahan persetujuan musnah, tidak lagi dapat diperdagangkan atau hilang, sedemikian hingga sama sekali tidak diketahui apakah barang itu masih ada". 2. Ajaran yang subjektif (de subjectieve overmachtsleer)

Menurut ajaran keadaan memaksa yang subjektif (relatif) keadaan memaksa itu ada apabila debitur masih mungkin melaksanakan prestasi tetapi dengan kesukaran atau pengorbanan yang besar sehingga dalam keadaan yang demikian itu kreditur tidak dapat menuntut pelaksanaan prestasi. Misalnya seorang penyanyi yang berjanji akan mengadakan pertunjukan. Sebelum pertunjukan diadakan ia mendengar berita tentang kematian anaknya hingga sukar bagi debitur untuk melaksanakan perjanjian itu. Bentuk keadaan memaksa terdiri dari bentuk yang umum yaitu keadaan iklim, kehilangan, pencurian, dan bentuk yang khusus yaitu undang-undang atau Peraturan Pemerintah, sumpah, tingkah laku pihak ketiga dan pemogokan.

Tanggung jawab dalam jual beli menurut KUH Perdata adalah dilihat menurut keadaan barang pada saat jual beli. Jika kebendaan yang dijual itu berupa suatu barang yang sudah ditentukan, maka barang ini sejak saat pembelian adalah atas tanggungan si pembeli, meskipun penyerahannya belum dilakukan, dan penjual berhak menuntut harganya (Pasal 1460). Jika barang-barang tidak dijual menurut tumpukan, tetapi menurut berat, jumlah atau ukuran, maka barang-barang itu tetap atas tanggungan si penjual hingga 
barang-barang ditimbng, dihitung atau diukur (Pasal 1461). Selanjutnya dalam Pasal 1462 jika sebaliknya barang-barang dijual menurut tumpukan, maka barang-barang itu adalah atas tanggungan si pembeli, meskipun belum ditimbang, dihitung atau diukur. Pasal 1460 KUH Perdata sekarang ini sudah tidak berlaku lagi berdasarkan pada Surat Edaran Mahkamah Agung Nomor 3 Tahun 1963 yang isinya adalah meminta kepada hakim agar tidak memperlakukan Pasal 1460 KUH Perdata karena pasal ini tidak sesuai dengan asas yaitu sifat obligatoir dari perjanjian yang dianut Indonesia, dan karena pasal ini menurut Mahkamah Agung mengadopsi dari code civil Perancis yang bersifat konsensual/final.

Dengan adanya Surat Edaran Mahkamah Agung Nomor 3 Tahun 1963 yang meminta kepada hakim agar tidak memperlakukan Pasal 1460 KUH Perdata, maka dalam hal ini terdapat kekosongan hukum jika seandainya hakim mengikuti anjuran dari Mahkamah Agung tersebut. Untuk mengisi kekosongan ini maka terhadap resiko jual beli yang mana barangnya sudah ditentukan maka digunakan ketentuan dari perjanjian tukar menukar sebagaimana diatur dalam Pasal 1545 KUH Perdata yaitu "Apabila barang itu hilang diluar kesalahan pemilik, perjanjian tukar menukar dianggap gugur. Apabila pihak lain terlanjur menyerahkan benda penggantinya maka benda itu dapat diminta kembali".

Berkaitan dengan tanggung jawab penyerahan barang dalam perjanjian jual beli termasuk juga dalam jual beli secara online berlaku ketentuan bahwa penjual bertanggung jawab atas penyerahan barang termasuk juga menanggung segala biaya penyerahan sedangkan biaya pengambilan ditanggung pembeli. Namun dalam transaksi jual beli secara onlinebiasanya dalam perjanjian jual belinya penjual membebankan biaya pengiriman pada konsumen.

Cara penyerahan barang yang menjadi objek jual beli seharusnya dilaksanakan ditempat dimana barang yang terjual berada pada waktu penjualan, namun dalam suasana jual beli secara onlinehal ini sangat tidak mungkin dilakukan sehingga penyerahan dilakukan tidak ditempat barang tersebut berada.

Walaupun pada dasarnya menurut ketentuan KUHPerdata penjual bertanggung jawab atas penyerahan barang, namun penjual dalam hal ini dapat melimpahkan tanggung jawabnya tersebut kepada pihak lain yaitu pihak jasa pengiriman, jika dalam perjanjian pengiriman barang terdapat klausul tersebut, atau jika tentang hal ini telah dimasukkan dalam salah satu butir perjanjian antara penjual dan pembeli. Dalam hal penjual melimpahkan tanggung jawabnya pada pihak jasa pengiriman, maka tanggung jawab resiko dan penyerahan tetap ada pada pihak penjual sebab antara pembeli dan pihak jasa pengiriman tidak ada hubungan hukum secara khusus, hubungan hukum pengiriman barang terjadi hanya antara penjual dengan pihak jasa pengiriman. Sehingga jika ada keterlambatan atau kerusakan pihak pembeli tetap melakukan tuntutan ganti kerugian pada pihak penjual, namun dalam hal ini pihak penjual dapat menarik pihak jasa pengiriman untuk bertanggung jawab sebagaimana perjanjian pengiriman barang yang disepakatinya, kecuali mengenai hal ini tidak diperjanjikan sebelumnya antara penjual dan pihak jasa pengiriman. Ketentuan yang demikian dibenarkan oleh hukum perjanjian, sebab sifat perjanjian menurut KUH Perdata adalah sebagai hukum pelengkap (aanvullend recht).

\section{PENUTUP}




\section{Kesimpulan}

Tanggung jawab levering pada perjanjian jual beli online berada pada penjual. Penjual bertanggung jawab atas penyerahan (levering) barang dalam jual beli namun terdapat pihak ketiga untuk menyerahkan barang yaitu pihak jasa pengiriman barang. Berdasarkan analisis hubungan hukum para pihak dalam jual beli online maka antara pembeli dan penjual berupa perjanjian jual beli,tidak ada hubungan hukum secara khusus antara pembeli dengan pihak jasa pengiriman, karena hubungan hukum pengiriman barang terjadi hanya antara pihak penjual dengan pihak jasa pengiriman. Sehingga jika ada keterlambatan atau kerusakan pihak pembeli tetap melakukan tuntutan ganti kerugian pada pihak penjual.Namun demikian, pihak penjual dapat menarik pihak jasa pengiriman barang untuk bertanggung jawab sesuai dengan kesepakatan dalam perjanjian pengiriman barang.

\section{Saran}

Agar terdapat kejelasan terkait tanggung jawab dalam leveringpada jual beli secara online, maka sebaiknya dalam perjanjian jual beli online para pihak membuat ketegasan dalam perjanjiannya.

\section{BIBLIOGRAFI}

Ali, Achmad. 2002. Menguak Tabir Hukum (Suatu Kajian Filosofis dan Sosiologis. Jakarta: Toko Gunung Agung Tbk.

--------, 2009. Menguak Teori Hukum (Legal Theory) Dan Teori Peradilan (Judicial Prudence) Termasuk Interpretasi Undang-Undang (Legisprudence). Jakarta: Prenada Media Group.

Badrulzaman, Mariam Darus.2001. Kompilasi Hukum Perikatan.Bandung: Citra Aditya Bakti.

Bingham, Tom. 2000. The Rule of Law. Lon- don: Penguins Book.

Dworkin, Ronald. 2002. Conception of Law and Morality dalam Wayne Morrison, Jurisprudence From the Greeks to Post Modernity. UK: Cavendish Publishing.

Garner, Bryan A. 2004. Black Law's Dictionary. $8^{\text {th }}$ edition. USA: Thompson West Group.

Hernoko, Agus Yudha. 2008. Hukum Perjanjian: Asas Proporsionalitas Dalam Kontrak Komersial. Yogyakarta: LBM.

Ibrahim, Johanes. 2004. Cross Default and Cross Collateral. Bandung: Refika Aditama.

Makarim, Edmon. 2005. Pengantar Hukum Telematika: Suatu Kompilasi Kajian. Jakarta: Rajagrafindo Persada.

Mertokusumo, Sudikno. 2003. Mengenal Hukum (Suatu Pengantar). Yogyakarta: Liberty.

Muhammad, Abdul Kadir. 1991. Pengantar Hukum Perusahaan Indonesia. Bandung: Citra Aditya Bakti.

Rahardjo,Satjipto. 2006. Hukum Dalam Jagat Ketertiban. Jakarta: Nuansa Cipta Warna.

Sidharta, Arief B. 1999. Refleksi Tentang Hukum,Bandung: Citra Aditya Bhakti.

Sofwan, Sri Soedewi Mascjhun.1976. Hukum Perdata: Hukum Benda, Yogyakarta: Seksi Hukum Perdata Fakultas Hukum UGM. 